\title{
Simvastatin antagonizes tumor necrosis factor- $\alpha$ inhibition of bone morphogenetic proteins-2-induced osteoblast differentiation by regulating Smad signaling and Ras/Rho-mitogen-activated protein kinase pathway
}

\author{
Misuzu Yamashita, Fumio Otsuka, Tomoyuki Mukai ${ }^{1}$, Hiroyuki Otani, Kenichi Inagaki, Tomoko Miyoshi, \\ Junko Goto, Masahiro Yamamura ${ }^{1}$ and Hirofumi Makino \\ Department of Medicine and Clinical Science, Okayama University Graduate School of Medicine, Dentistry and Pharmaceutical Sciences, 2-5-1 Shikata-cho, \\ Okayama City 700-8558, Japan \\ ${ }^{1}$ Department of Rheumatology, School of Medicine, Aichi Medical University, Aichi 480-1195, Japan \\ (Correspondence should be addressed to F Otsuka; Email: fumiotsu@md.okayama-u.ac.jp)
}

\begin{abstract}
Recent studies have shown that the mevalonate pathway plays an important role in skeletal metabolism. Statins stimulate bone morphogenetic proteins-2 (BMP-2) production in osteoblasts, implicating a possible beneficial role for statins in promoting anabolic effects on bone. Here, we investigated the effects of a lipophilic simvastatin on osteoblast differentiation using mouse myoblast $\mathrm{C} 2 \mathrm{C} 12$ cells, in the presence of tumor necrosis factor- $\alpha$ (TNF- $\alpha$ ), an inflammatory cytokine that inhibits osteogenesis. The addition of TNF- $\alpha$ to $\mathrm{C} 2 \mathrm{C} 12$ cells suppressed the BMP-2-induced expression of key osteoblastic markers including Runx2 and alkaline phosphatase (ALP) activity. Simvastatin had no independent effects on Runx2 and alkaline phosphatase activity; however, it reversed the suppressive effects of TNF- $\alpha$. The ability of simvastatin to reverse TNF- $\alpha$ inhibition of BMP-induced Smad1,5,8 phosphorylation and Id-1 promoter activity suggests the involvement of Smad signaling pathway in simvastatin action. In addition, cDNA array analysis revealed that simvastatin increased expression levels of Smads in
\end{abstract}

C2C12 cells exposed to TNF- $\alpha$ that also activated mitogenactivated protein kinase (MAPK) signaling pathways, including extracellular signal-regulated kinase 1/2 (ERK1/2), P38, and stress-activated protein kinase/c-Jun NH2-terminal kinase (SAPK/JNK). Simvastatin potently suppressed TNF$\boldsymbol{\alpha}$-induced phosphorylation of ERK1/2 and SAPK/JNK by inhibiting TNF- $\alpha$-induced membrane localization of Ras and RhoA. Farnesyl pyrophosphate (FPP) and geranylgeranyl pyrophosphate (GGPP) reversed the simvastatin effects on TNF- $\alpha$-induced activation of Ras/Rho/MAPK pathways. FPP and GGPP also restored the simvastatin effects on TNF$\alpha$-induced suppression of Runx 2 and ALP activity. In addition, simvastatin decreased the expression levels of TNF type-1 and -2 receptor mRNAs. Collectively, simvastatin supports BMP-induced osteoblast differentiation through antagonizing TNF- $\boldsymbol{\alpha}$-to-Ras/Rho/MAPK pathway and augmenting BMP-Smad signaling, suggesting a potential usage of statins to ameliorate inflammatory bone damage.

Journal of Endocrinology (2008) 196, 601-613

\section{Introduction}

Bone morphogenetic proteins (BMPs), members of the transforming growth factor (TGF)- $\beta$ superfamily, have established critical roles in governing various aspects of embryological development, including brain, heart, kidney, and eyes (Reddi 1997). BMPs also play a pivotal regulatory role in mesoderm induction and dorsoventral patterning of developing limb buds and are known to promote differentiation of mesenchymal stem cells into chondrocytes and osteoblasts as well as the differentiation of osteoprogenitor cells into osteoblasts (Lieberman et al. 2002). The biological functions of BMPs are mediated through the Smad signal transduction pathway via BMP receptors. In addition to the established developmental actions of BMPs, a variety of physiological BMP actions in many endocrine and vascular tissues including the ovary (Otsuka et al. 2000, Shimasaki et al. 2004), pituitary (Otsuka \& Shimasaki 2002), thyroid (Suzuki et al. 2005), adrenal (Suzuki et al. 2004, Kano et al. 2005, Inagaki et al. 2006), kidney (Otani et al. 2007), and vascular smooth muscle cells (Takeda et al. 2004) have been elucidated.

Osteoblasts, which arise from mesenchymal stem cell precursors, undergo differentiation in response to a number of factors including BMPs, TGFs, insulin-like growth factor-I (IGF-I), vascular endothelial growth factor (VEGF), and steroids (McCarthy et al. 1989, Noda \& Camilliere 1989, Celeste et al. 1990, Midy \& Plouet 1994, Hughes et al. 1995, Goad et al. 1996, Gerber et al. 1999, Spelsberg et al. 1999). 
Once matrix synthesis begins in cultured osteoblast cells, they differentiate and osteoblastic markers including alkaline phosphatase (ALP), type-I collagen and osteocalcin are activated. Osteoblasts then embed in the extracellular matrix consisting of collagen fibrils, and the matrix is mineralized and extended in the collagen fibrils. Deposition and maintenance of mineralized skeletal elements are further regulated by various growth factors and cytokines.

Mundy et al. (1999) first reported that statins stimulate in vivo bone formation in rodents and increase new bone volume in mouse calvaria cell cultures. Statins also stimulate expression of bone anabolic factors, such as VEGF and BMP-2 (Maeda et al. 2003), and promote osteoblast differentiation and mineralization in MC3T3-E1 cells derived from new bone mouse calvaria (Maeda et al. 2001). Statins are potent inhibitors of cholesterol biosynthesis widely used to reduce serum cholesterol levels in hyperlipidemic patients (Hamelin \& Turgeon 1998, Maron et al. 2000). Statins inhibit 3-hydroxy-3-methylglutarylcoenzyme A (HMG-CoA) reductase to block the conversion of HMG-CoA to mevalonate, a rate-limiting step in cholesterol synthesis (Goldstein \& Brown 1990). By inhibiting the initial part of the cholesterol synthesis pathway, statins decrease the availability of several important lipid intermediate compounds including isoprenoids such as farnesyl pyrophosphate (FPP) and geranylgeranyl pyrophosphate (GGPP). These compounds are associated with post-translational modification of various small G-proteins including Ras and Ras-like proteins such as Rho, Rac, and Rab (Casey \& Seabra 1996), which interact with the downstream mitogen-activated protein kinases (MAPKs) and play a central role in cellular responses such as cell proliferation, apoptosis, migration, and gene expression.

Little is known, however, about cellular mechanisms of statin actions in regulating osteoblast function. The present study was undertaken to investigate changes in marker expression corresponding to stages of osteoblast differentiation in statin-treated $\mathrm{C} 2 \mathrm{C} 12$ cells focusing on the effects of a critical inflammatory cytokine, tumor necrosis factor (TNF)- $\alpha$. The pluripotent mesenchymal precursor cell line C2C12, a subclone of a mouse myoblastic cell line, has been widely used as a model to examine the early stages of osteoblast differentiation during bone formation in muscular tissues (Katagiri et al. 1994, Ebisawa et al. 1999). Macrophages play a key role in chronic inflammation and joint destruction of rheumatoid arthritis by secreting pro-inflammatory cytokines including TNF- $\alpha$ (Feldmann et al. 1996). The clinical effectiveness of blocking TNF- $\alpha$ in treating active rheumatoid arthritis established the pathogenic significance of TNF- $\alpha$ in this disease (Feldmann \& Maini 2001, Scott \& Kingsley 2006). TNF- $\alpha$ produced by macrophages and inflammatory cells induces apoptosis or necrosis in various other cell types. TNF- $\alpha$ induces osteoclast differentiation leading to excess of bone resorption (Kudo et al. 2002). Since bone loss in arthritis is related to the activation of TNF- $\alpha$ system, it can be hypothesized that TNF- $\alpha$ also directly controls osteoblast survival and/or osteoblast function related to bone formation. However, roles of the TNF- $\alpha$ signaling system in determining osteoblast function and its differentiation remain unsolved.

In the present study, we investigated the effects of a lipophilic simvastatin and TNF- $\alpha$ on osteoblast differentiation using mouse myoblast $\mathrm{C} 2 \mathrm{C} 12$ cells. This study shows that simvastatin supports BMP-induced osteoblast differentiation by antagonizing TNF- $\alpha$-to-MAPK pathway and augmenting BMP-Smad signaling, suggesting a potential usage of simvastatin to ameliorate inflammatory bone damages shown in rheumatoid arthritis.

\section{Materials and Methods}

\section{Reagents and supplies}

Dulbecco's modified Eagle's medium (DMEM), penicillinstreptomycin solution, dimethylsulfoxide, FPP and GGPP were purchased from Sigma-Aldrich Co. Ltd. Recombinant human TNF- $\alpha$ was obtained from PeproTech EC Ltd (London, UK), and recombinant human BMP-2 was purchased from R\&D Systems Inc. (Minneapolis, MN, USA). Simvastatin was provided by Merck \& Co. Inc., and converted to the active form by alkaline hydrolysis. Id-1-Luc plasmid was kindly provided from Drs Tetsuro Watabe and Kohei Miyazono, Tokyo University (Japan).

\section{Cell culture}

The mouse myoblast cell line $\mathrm{C} 2 \mathrm{C} 12$ was obtained from American Type Culture Collection (Manassas, VA, USA). C2C12 cells were cultured in DMEM supplemented with $10 \%$ fetal calf serum (FCS) and penicillin-streptomycin solution at $37^{\circ} \mathrm{C}$ under a humid atmosphere of $95 \%$ air $/ 5 \%$ $\mathrm{CO}_{2}$. Changes in cell morphology were monitored using an inverted microscope.

\section{$R N A$ extraction and quantitative real-time $R T-P C R$ analysis}

To prepare total cellular RNA, C2C12 cells were cultured in a 12 -well plate $\left(2 \times 10^{5}\right.$ viable cells $)$ and treated with indicated concentrations of BMP-2, TNF- $\alpha$, simvastatin, and either FPP or GGPP in serum-free DMEM. After 48-h culture, the medium was removed, and total cellular RNA was extracted using TRIzol (Invitrogen Corp.), quantified by measuring absorbance at $260 \mathrm{~nm}$, and stored at $-80^{\circ} \mathrm{C}$ until assay. The extracted RNA $(1 \cdot 0 \mu \mathrm{g})$ was subjected to an RT reaction using the First-Strand cDNA synthesis system (Invitrogen Corp.) with random hexamer $(2 \mathrm{ng} / \mu \mathrm{l})$, reverse transcriptase $(200 \mathrm{U})$, and deoxy-NTP $(0.5 \mathrm{mM})$ at 42 and $70{ }^{\circ} \mathrm{C}$ for 50 and $10 \mathrm{~min}$ respectively. Oligonucleotides used for RT-PCR were custom ordered from Invitrogen Corp. PCR primer pairs were selected from different exons of the corresponding genes as follows: Runx2, 981-999, and 
1291-1310 (from GenBank accession no. NM_009820); TNF type-1 receptor (TNFR1), 931-951 and 1211-1231 (BC052675); TNF type-2 receptor (TNFR2), 142-162 and 1142-1162 (Y14622); and a house-keeping gene, ribosomal protein L19 (RPL19), 373-393 and 547-567 (NM_009078). For the quantification of Runx2, TNFR1, TNFR2, and RPL19 mRNA levels, real-time PCR was performed using LightCycler-FastStart DNA Master SYBR Green I system (Roche Diagnostic Co.) under conditions of annealing at 60-62 ${ }^{\circ} \mathrm{C}$ with $4 \mathrm{mM} \mathrm{MgCl}_{2}$, following the manufacturer's protocol. Accumulated levels of fluorescence were analyzed by the second derivative method after the melting curve analysis (Roche Diagnostic), and then the expression levels of target genes were standardized by RPL19 level in each sample.

\section{ALP determination}

After preculture with serum-free DMEM, cells $\left(1 \times 10^{5}\right.$ viable cells) were treated with indicated concentrations of BMP-2, TNF- $\alpha$, simvastatin, and either FPP or GGPP in 12-well plates. After 72-h culture, cells were lysed and cellular ALP activity was measured by a fluorometric detection kit using 4-methylumbelliferyl phosphate disodium substrate (Sigma Chemical Co). ALP activity of each sample was normalized by protein concentration.

\section{Western immunoblot analysis}

Cells $\left(2 \times 10^{5}\right.$ viable cells) were precultured in 12 -well plates in DMEM containing 10\% FCS for $48 \mathrm{~h}$. After preculture, the medium was replaced with serum-free fresh medium, and then indicated concentrations of BMP-2, TNF- $\alpha$, simvastatin, FPP, and GGPP were added to the culture medium. After stimulation with growth factors for indicated periods, the membrane fraction of C2C12 cells was extracted by ProteoExtract Native Membrane Protein Extraction Kit (Calbiochem, San Diego, CA, USA). Cells and membrane fraction were solubilized in $100 \mu \mathrm{l}$ RIPA lysis buffer (Upstate Biotechnology Inc., Lake Placid, NY, USA) containing $1 \mathrm{mM} \mathrm{Na} \mathrm{VO}_{4}, 1 \mathrm{mM}$ sodium fluoride, $2 \%$ SDS, and $4 \% \beta$-mercaptoethanol. Total cell lysates and the membrane fraction were then subjected to SDSPAGE/immunoblotting analysis, as reported previously (Inagaki et al. 2006) using anti-Runx2 (S-19) antibody (Santa Cruz Biotechnology, Santa Cruz, CA, USA), anti-actin antibody (Sigma-Aldrich Co. Ltd), anti-phospho-Smad1,5,8 antibody (Cell Signaling Technology Inc., Beverly, MA, USA), antiphospho- and anti-total-extracellular signal-regulated kinase (ERK)1/2 MAPK antibodies (Cell Signaling Technology Inc.), anti-phospho- and anti-total-P38 MAPK antibodies (Cell Signaling Technology Inc.), anti-phospho- and anti-totalstress-activated protein kinase/c-Jun NH2-terminal kinase (SAPK/JNK) MAPK antibody (Cell Signaling Technology Inc.), and anti-pan-Ras and anti-RhoA antibody (Santa Cruz Biotechnology).
Transient transfection and luciferase assay

C2C12 cells $\left(1 \times 10^{5}\right.$ viable cells) were precultured in 12 -well plates in DMEM with 10\% FCS for $48 \mathrm{~h}$. The cells were then transiently transfected with 500 ng Id-1-Luc reporter plasmid and 50 ng cytomegalovirus- $\beta$-galactosidase plasmid (pCMV$\beta$-gal) using FuGENE6 (Roche Molecular Biochemicals) for $24 \mathrm{~h}$. The cells were pretreated with indicated concentrations of BMP-2 and simvastatin for $24 \mathrm{~h}$ in serum-free fresh medium and then incubated with TNF- $\alpha$. After 24-h culture, the cells were washed with PBS and lysed with Cell Culture Lysis Reagent (Toyobo, Osaka, Japan). Luciferase and $\beta$-galactosidase ( $\beta$-gal) activities of the cell lysate were measured by luminescencer-PSN (ATTO, Tokyo, Japan), as reported previously (Miyoshi et al. 2006). The data were shown as the ratio of luciferase to $\beta$-gal activity.

\section{$c D N A$ array analysis}

Oligo GEArray system (SuperArray Bioscience Corp., Frederick, MD, USA) that includes 113 genes of mouse TGF- $\beta$ and BMP signaling pathway was used for analyzing the expression pattern of BMP signaling system in $\mathrm{C} 2 \mathrm{C} 12$ cells. As we reported previously (Miyoshi et al. 2006, Otani et al. 2007), extracted total RNAs $(2 \cdot 0 \mu \mathrm{g})$ were used as templates to generate biotin-16-dUTP-labeled cDNA probes according to manufacturer's instruction. The cDNA probes were denatured and hybridized at $60^{\circ} \mathrm{C}$ with the cDNA array membranes, which were washed and exposed to X-ray films with use of chemiluminescent substrates. To analyze the array results, we scanned the $\mathrm{X}$-ray film and the image was inverted as grayscale TIFF files. The spots were digitized and analyzed using GEArray analyzer software (SuperArray Bioscience Corp.), and the data were normalized by subtraction of the background as the average intensity levels of plasmid DNA of pUC18. The spots of glyceraldehyde-3-phosphate dehydrogenase and cyclophilin A (PPIA) were used as positive controls to compare the membranes. Using these standardized data, we compared the signal intensity of the membranes using the GEArray analyzer program (SuperArray Bioscience Corp.).

\section{Statistical analysis}

All results are shown as mean \pm s.E.M. of data from at least three separate experiments, each performed with triplicate samples. Differences between groups were analyzed for statistical significance using ANOVA (StatView 5.0 software, Abacus Concepts Inc., Berkeley, CA, USA). P values $<0 \cdot 05$ were accepted as statistically significant.

\section{Results}

We first examined the expression profile of Runx2, also called core-binding factor 1 (Cbfa1), induced by BMP-2 treatment 
in C2C12 cells. Runx2 is an important bone-specific transcription factor, which is essential for the differentiation of osteoblasts from mesenchymal precursors (Komori et al. 1997, Otto et al. 1997). Runx2 can directly stimulate transcription of osteoblast-related genes such as those encoding osteocalcin, type I collagen, osteopontin, and collagenase 3 by binding to specific enhancer regions (Ducy et al. 1997). Runx 2 mRNA levels were significantly increased in the presence of BMP-2 $(100 \mathrm{ng} / \mathrm{ml})$ and attained the highest at $48-\mathrm{h}$ culture condition (Fig. 1A). Runx2 protein levels were also enhanced by BMP-2 treatment in accordance with the time-dependent changes of Runx2 mRNA (Fig. 1B). Simvastatin effects on Runx 2 mRNA levels were then characterized in the presence or absence of BMP-2. Simvastatin alone $(1-100 \mu \mathrm{M})$ had no effects on endogenous Runx2 expression (Fig. 1C). BMP-2 (100 ng/ml) increased levels of Runx2 mRNA expression 2- to 2.5-fold during 48-h culture. Simvastatin (1-30 $\mathrm{MM})$ had no significant effects on BMP-2-induced Runx2 mRNA expression although a high concentration $(100 \mu \mathrm{M})$ of simvastatin had an inhibitory effect on BMP-2-induced Runx2 expression (Fig. 1C). Based on these results, $1-30 \mu \mathrm{M}$ simvastatin was used for the following experiments of C2C12 cells.

We next investigated the effects of simvastatin on TNF- $\alpha$ action, which inhibits BMP-2-stimulated osteogenetic properties. C2C12 cells were cultured with TNF- $\alpha$ and BMP-2 in the presence or absence of simvastatin $(3-30 \mu \mathrm{M})$. As shown in Fig. 2A, in the absence of simvastatin, BMP-2-induced Runx2 expression was potently suppressed by TNF- $\alpha(10-30 \mathrm{ng} / \mathrm{ml})$ in a concentration-responsive manner. Notably, simvastatin impaired the Runx 2 mRNA suppression induced by TNF- $\alpha$ in the presence of BMP-2 (Fig. 2A). To confirm the effect of simvastatin at the protein levels, cellular ALP activity was examined in $\mathrm{C} 2 \mathrm{C} 12$ cells. Consistent with the simvastatin effects on Runx2 expression, simvastatin also suppressed TNF$\boldsymbol{\alpha}$-induced reduction of ALP activity stimulated by BMP-2 (Fig. 2B). Thus, simvastatin concentration-dependently blocked the TNF- $\alpha$ effects that suppress osteoblastic differentiation elicited by BMP-2.

We further investigated the effects of simvastatin pretreatment on Runx2 expression and ALP activity modulated by TNF- $\alpha$. Following 24-h pretreatment with simvastatin (1 and $10 \mu \mathrm{M}), \mathrm{C} 2 \mathrm{C} 12$ cells were cultured with BMP-2 $(100 \mathrm{ng} / \mathrm{ml})$ and TNF- $\alpha(10 \mathrm{ng} / \mathrm{ml})$. When cells were pretreated with simvastatin, the TNF- $\alpha$ effect suppressing BMP-2-induced Runx2 expression was significantly impaired (Fig. 3). In statin-pretreated cells, the peak response of BMP-2-induced ALP activity was potently enhanced (Fig. 4) while the induction of Runx2 mRNA was not affected (Fig. 3). In addition, the TNF- $\alpha$ suppression of ALP activity induced by BMP-2 was also reversed by pretreatment with simvastatin (Fig. 4). Thus, simvastatin might enhance osteoblast differentiation by regulating Runx2 expression and ALP activity through augmenting BMP-2 actions in C2C12 cells.
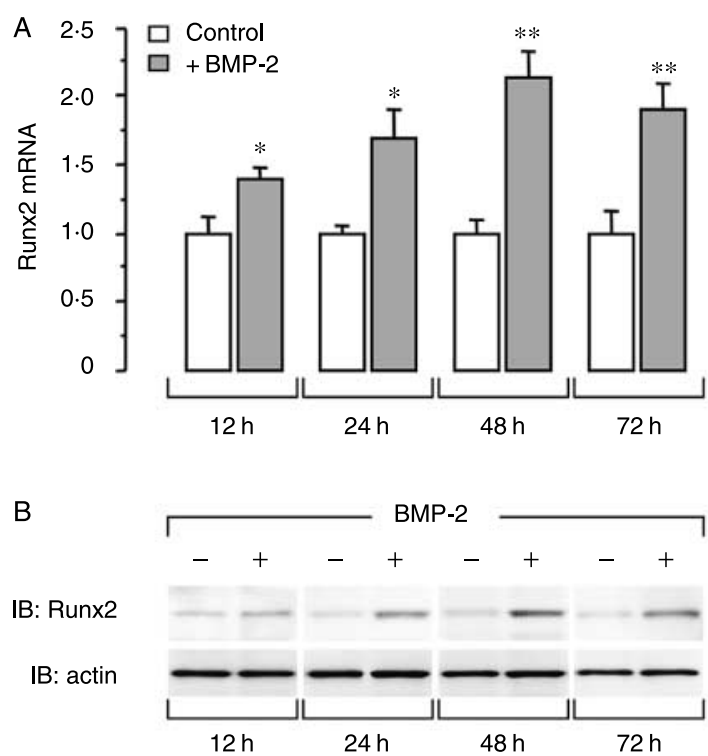

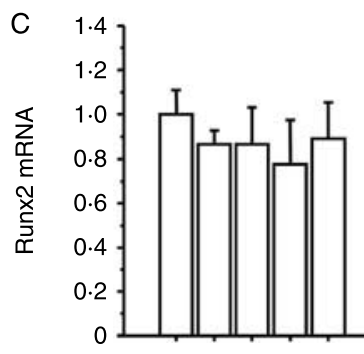

Simvastatin $(\mu \mathrm{M}) \quad 0 \quad 1 \quad 1030100$ BMP-2 (ng/ml) 0000000

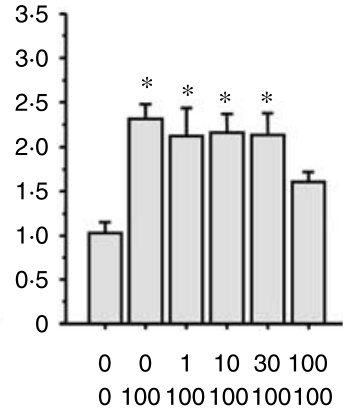

Figure 1 Characterization of Runx2 expression in C2C12 cells and simvastatin effects on BMP-induced Runx2 expression. (A) Timecourse changes of BMP-2-induced Runx2 mRNA expression. C2C12 cells were cultured in the absence or presence of BMP-2 $(100 \mathrm{ng} / \mathrm{ml})$ for $72 \mathrm{~h}$. Total cellular RNA was extracted and subjected to RT reaction. For the quantification of Runx2 and RPL19 mRNA levels, quantitative real-time PCR (qPCR) was performed. The expression level of Runx2 was standardized by RPL19 level in each sample. Results are shown as mean \pm s.E.M. of data from at least three separate experiments, each performed with triplicate samples. $* P<0 \cdot 05$ and ${ }^{* *} P<0 \cdot 01$ versus control levels. (B) Time-course changes of BMP-2-induced Runx2 protein expression. Cells were incubated in the absence or presence of BMP-2 $(100 \mathrm{ng} / \mathrm{ml})$ for $72 \mathrm{~h}$. At each time point, cells were lysed and subjected to SDSPAGE/immunoblot (IB) analysis using antibodies that detect Runx2 protein $(55 \mathrm{kDa})$ and an internal control actin. The results shown are representative of those obtained from three independent experiments. (C) Simvastatin effects on BMP-induced Runx2 mRNA expression. Cells were treated with simvastatin $(1-100 \mu \mathrm{M})$ in the absence or presence of BMP-2 $(100 \mathrm{ng} / \mathrm{ml})$ for $48 \mathrm{~h}$. Total cellular RNA was extracted and subjected to qPCR analysis as described above. Results are shown as mean \pm s.E.M. of data from at least three separate experiments, each performed with triplicate samples. $* P<0 \cdot 05$ versus control levels. 
A

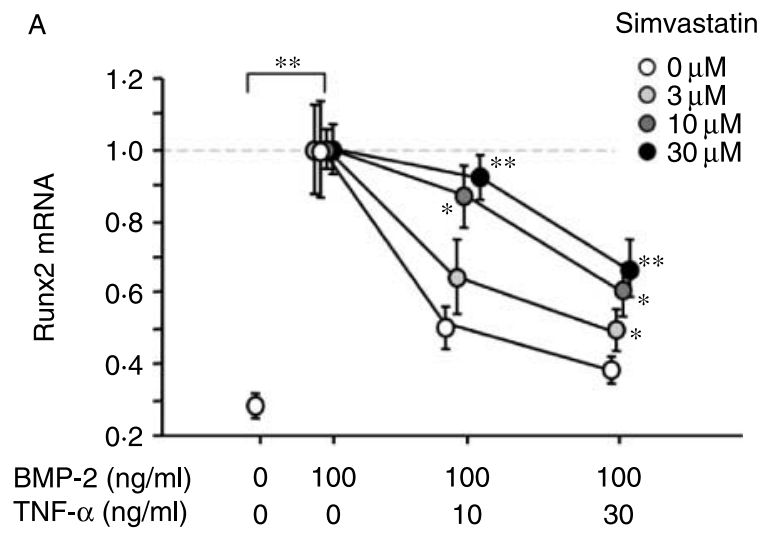

B

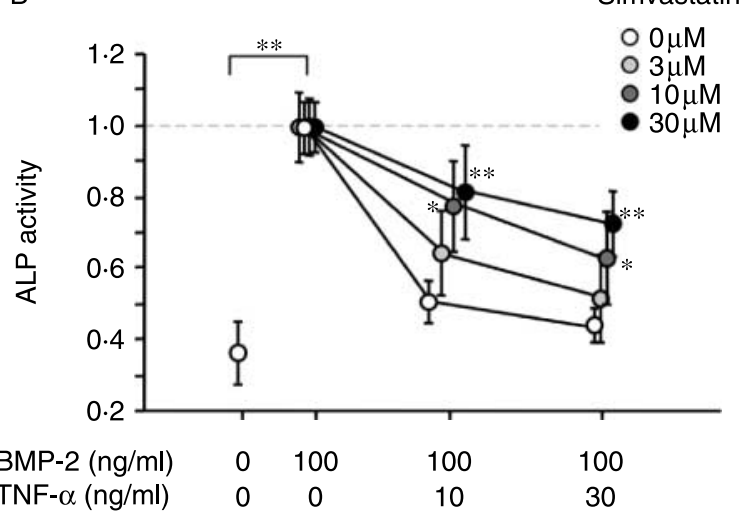

Figure 2 Simvastatin effects on TNF- $\alpha$ suppression of BMP-induced Runx2 expression and alkaline phosphatase (ALP) activity. (A) Simvastatin effects on TNF- $\alpha$ suppression of BMP-induced Runx2 expression. Cells were treated with simvastatin $(3-30 \mu \mathrm{M})$ in the presence of BMP-2 $(100 \mathrm{ng} / \mathrm{ml})$ and TNF- $\alpha(10$ and $30 \mathrm{ng} / \mathrm{ml})$ for $48 \mathrm{~h}$. Total cellular RNA was extracted and subjected to RT reaction. For the quantification of Runx2 and RPL19 mRNA levels, qPCR analysis was performed. The expression level of Runx2 was standardized by RPL19 level in each sample. Results are shown as mean \pm S.E.M. of data from at least three separate experiments, each performed with triplicate samples. ${ }^{*} P<0 \cdot 05$ and ${ }^{* *} P<0 \cdot 01$ versus simvastatin-free control groups or between the indicated groups. (B) Simvastatin effects on TNF- $\alpha$ suppression of BMP-induced ALP activity. Cells were treated with simvastatin $(3-30 \mu \mathrm{M})$ in the presence of BMP-2 $(100 \mathrm{ng} / \mathrm{ml})$ and TNF- $\alpha(10$ and $30 \mathrm{ng} / \mathrm{ml})$ for $72 \mathrm{~h}$. Cells were lysed and cellular ALP activity was measured by fluorometric method. Results are shown as mean \pm s.E.M. of data from at least three separate experiments, each performed with triplicate samples. ${ }^{*} P<0 \cdot 05$ and ${ }^{* *} P<0 \cdot 01$ versus simvastatin-free control groups or between the indicated groups.

In order to investigate the mechanism by which simvastatin cooperates BMP effects, time-course changes of a key BMP signaling, phospho-Smad1,5,8 proteins were detected by western blotting analysis. As shown in Fig. 5A, BMP-2 stimulated Smad1,5,8 phosphorylation. Neither simvastatin nor TNF- $\alpha$ independently had any effect on the Smad1,5,8 activation (Fig. 5A); however, TNF- $\alpha$ inhibited BMP-2induced Smad1,5,8 phosphorylation (Fig. 5B). Densitometric analysis of band intensities showed that simvastatin partially
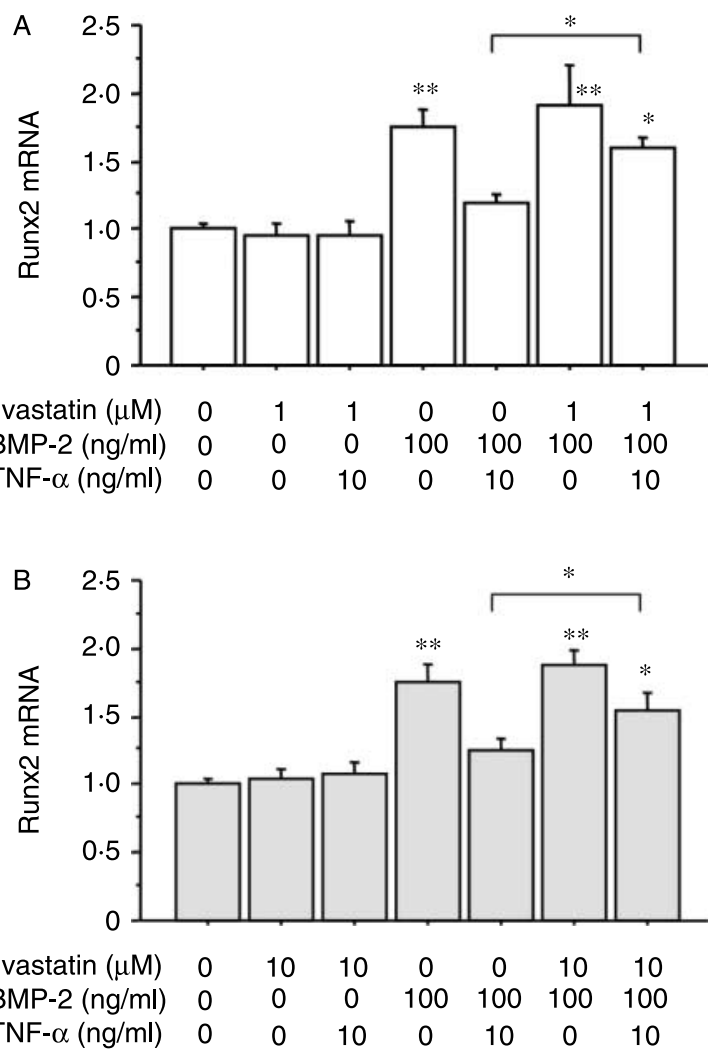

Figure 3 Effects of simvastatin pretreatment on TNF- $\alpha$ suppression of BMP-induced Runx2 expression. After preculture, the cells were pretreated with simvastatin (A: $1 \mu \mathrm{M}$ and $\mathrm{B}: 10 \mu \mathrm{M})$ in combination with BMP-2 $(100 \mathrm{ng} / \mathrm{ml})$ for $24 \mathrm{~h}$, and then cells were treated with TNF- $\alpha(10 \mathrm{ng} / \mathrm{ml})$ for $48 \mathrm{~h}$. Total cellular RNA was extracted and subjected to RT reaction. For the quantification of Runx2 and RPL19 mRNA levels, qPCR analysis was performed. The expression level of Runx2 was standardized by RPL19 level in each sample. Results are shown as mean \pm S.E.M. of data from at least three separate experiments, each performed with triplicate samples. ${ }^{*} P<0.05$ and ${ }^{* *} P<0 \cdot 01$ versus control groups or between the indicated groups.

reversed Smad1,5,8 inactivation caused by TNF- $\alpha$ (Fig. 5B and $\mathrm{C})$. To confirm this finding, we assessed a BMP target gene Id-1 promoter activity using cells transiently transfected with Id-1-Luc (Fig. 5D). In accordance with western blot data of Smad1,5,8 phosphorylation, Id-1-Luc activity elicited by BMP-2 was significantly suppressed by TNF- $\alpha$. Importantly, 24-h pretreatment with simvastatin restored the suppression of BMP-2-induced Id-1 transcription caused by TNF- $\alpha$. These results suggest that simvastatin maintains BMP-Smad signaling in C2C12 cells in spite of the TNF- $\alpha$ effects.

BMP type-I receptors, including ALK-2, ALK-3, and ALK-4; type II receptors, including BMPRII, ActRII, and ActRIIB; and Smad signaling molecules, including Smad1, 2, $3,4,5,6,7$, and 8 were clearly expressed in this cell line as reported earlier by RT-PCR (Mukai et al. 2007). ALK-6 is not expressed in $\mathrm{C} 2 \mathrm{C} 12$ cells. To investigate the mechanism by which simvastatin maintains the BMP signaling in $\mathrm{C} 2 \mathrm{C} 12$ cells, cDNA array analysis in BMP/TGF- $\beta$ signaling 


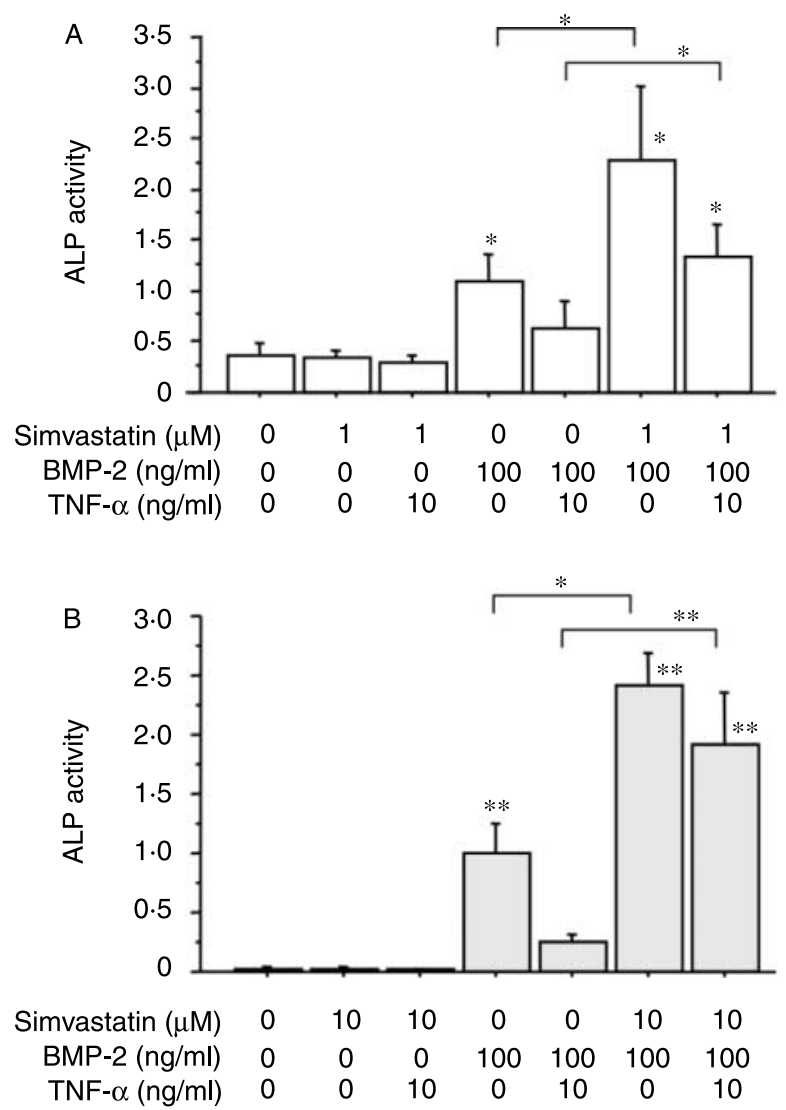

Figure 4 Effects of simvastatin pretreatment on TNF- $\alpha$ suppression of BMP-induced alkaline phosphatase (ALP) activity. After preculture, the cells were pretreated with simvastatin (A: $1 \mu \mathrm{M}$ and $\mathrm{B}: 10 \mu \mathrm{M})$ in combination with BMP-2 $(100 \mathrm{ng} / \mathrm{ml})$ for $24 \mathrm{~h}$, and then cells were treated with TNF- $\alpha(10 \mathrm{ng} / \mathrm{ml})$ for $72 \mathrm{~h}$. Cells were lysed and cellular ALP activity was measured by fluorometric method. Results are shown as mean \pm s.E.M. of data from at least three separate experiments, each performed with triplicate samples. ${ }^{*} P<0.05$ and ${ }^{* *} P<0.01$ versus control groups or between the indicated groups.

molecules was performed using total cellular RNAs extracted from C2C12 cells treated with TNF- $\alpha(10 \mathrm{ng} / \mathrm{ml})$ alone and TNF- $\alpha(10 \mathrm{ng} / \mathrm{ml})$ plus simvastatin $(10 \mu \mathrm{M})$ for $24 \mathrm{~h}$ (Fig. 6A). Among the key regulatory genes for BMP-Smad activation in C2C12 cells, the enhanced expression of Smad1, 2 , and 3 in the cells treated with simvastatin was noted (Fig. 6B), suggesting that increased Smad expression by simvastatin may be involved in facilitating BMP-Smad1,5,8 activation.

There has been increasing evidence suggesting that TNF- $\alpha$ activates MAPK signaling pathway in various cells including C2C12 cells, although the physiological roles of MAPK activation has yet to be elucidated. As demonstrated in Fig. 7A, BMP-2 alone $(100 \mathrm{ng} / \mathrm{ml})$ had no effect on MAPK activation, including the ERK1/2, P38, and SAPK/JNK pathways. In contrast, TNF- $\alpha(100 \mathrm{ng} / \mathrm{ml})$ activated phosphorylation of ERK1/2, P38, and SAPK/JNK signaling regardless of the presence of BMP-2 (Fig. 7A). Densitometric analysis of band intensities showed that phosphorylation of ERK1/2 and SAPK/JNK, but not P38, pathways induced by TNF- $\alpha$ was significantly inhibited by co-treatment with simvastatin $(10 \mu \mathrm{M}$; Fig. $7 \mathrm{~B})$. The simvastatin effect on inhibiting MAPK activation was not influenced by BMP-2 (Fig. 7B). To determine whether statins regulate the activity of small G-proteins, which are upstream components of MAPK cascades, we next examined the membrane localization of Ras and RhoA. Stimulation with TNF- $\alpha$ $(100 \mathrm{ng} / \mathrm{ml})$ potently increased the level of membrane-bound Ras and RhoA, whereas the effects of simvastatin and BMP-2 were negligible (Fig. 8). Of note, simvastatin $(10 \mu \mathrm{M})$ significantly blocked TNF- $\boldsymbol{\alpha}$-induced $\mathrm{R}$ as and RhoA membrane localization without affecting the total amount of these proteins in C2C12 cells (Fig. 8).

The inhibitory effect of simvastatin $(10 \mu \mathrm{M})$ on TNF- $\alpha-$ induced $\mathrm{R}$ as localization was preferentially restored by FPP $(5 \mu \mathrm{M})$, while that on TNF- $\boldsymbol{\alpha}$-induced RhoA localization was reversed by FPP $(5 \mu \mathrm{M})$ as well as GGPP $(5 \mu \mathrm{M}$; Fig. 9A). FPP also reversed inhibitory effects of simvastatin on ERK1/2 and SAPK/JNK phosphorylation induced by TNF- $\alpha$ (Fig. 9B). GGPP predominantly restored the simvastatin effects on inhibiting TNF- $\alpha$-induced SAPK/JNK phosphorylation (Fig. 9B). Furthermore, the simvastatin effects on TNF- $\alpha$ suppression of BMP-2-induced Runx2 expression and ALP activity were reversed in the presence of FPP and GGPP (Fig. 9C), suggesting that simvastatin antagonizes TNF- $\alpha$ effects, at least in part, by regulating Ras/Rho-to-MAPK pathway.

To investigate the effect of simvastatin on TNF- $\alpha$ sensitivity, changes in TNF receptor (TNFR) mRNA expression in $\mathrm{C} 2 \mathrm{C} 12$ cells were examined in the presence of simvastatin using quantitative real-time PCR. These experiments demonstrated that simvastatin (1 and $10 \mu \mathrm{M})$ significantly decreased expression levels of both TNFR 1 and TNFR2 (Fig. 10). TNF- $\alpha$ moderately reduced TNFR1 mRNA expression and had no effect on the expression of TNFR2 (Fig. 10). Thus, simvastatin has dual inhibitory effects on the TNFR signaling, including TNFR expression and the downstream ERK1/2 and SAPK/JNK pathways through Ras/Rho activation (Fig. 11).

\section{Discussion}

We recently reported that TNF- $\alpha$ suppresses BMP-2-induced expression of osteoblast markers such as Runx2, osteocalcin, and ALP activity (Mukai et al. 2007). Importantly, the inhibition of MAPK pathways, in particular SAPK/JNK, restored TNF- $\alpha$ effects on BMP-induced osteoblast differentiation, suggesting that SAPK/JNK pathway is a key regulator for suppressing BMP signaling caused by TNF- $\alpha$ (Mukai et al. 2007). In the present study, we further demonstrated that simvastatin inhibits TNF- $\alpha$ effects in $\mathrm{C} 2 \mathrm{C} 12$ cells, leading to maintenance of osteoblast differentiation induced by BMP-2 (Fig. 11). TNF- $\alpha$ suppressed the expression of osteoblastic 
A

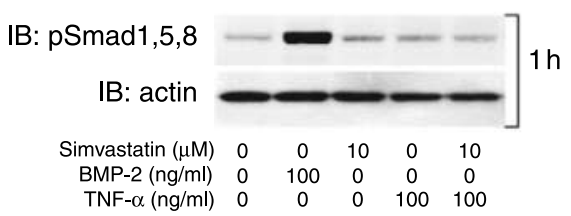

B

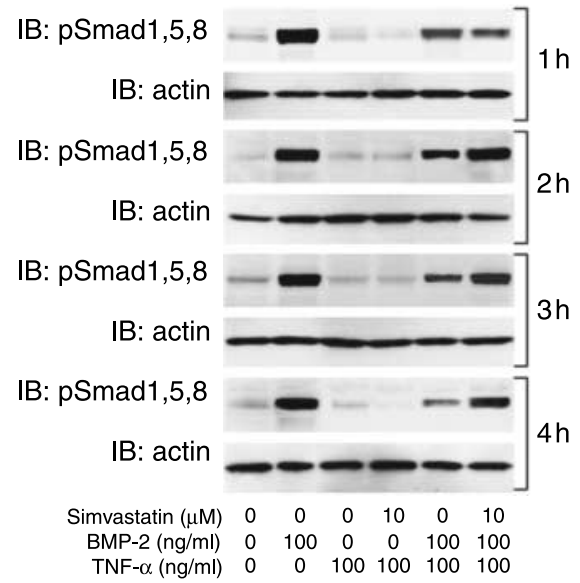

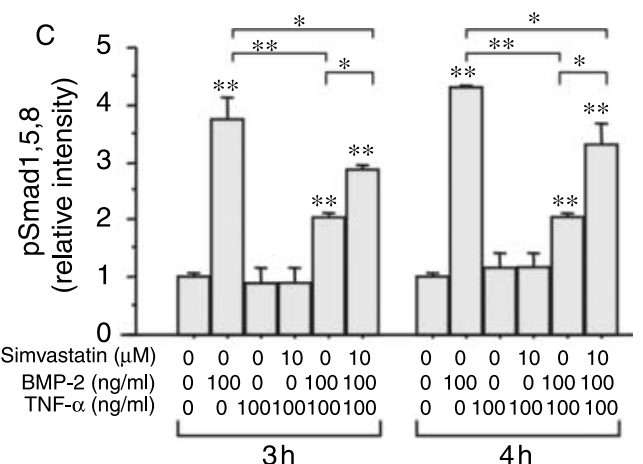

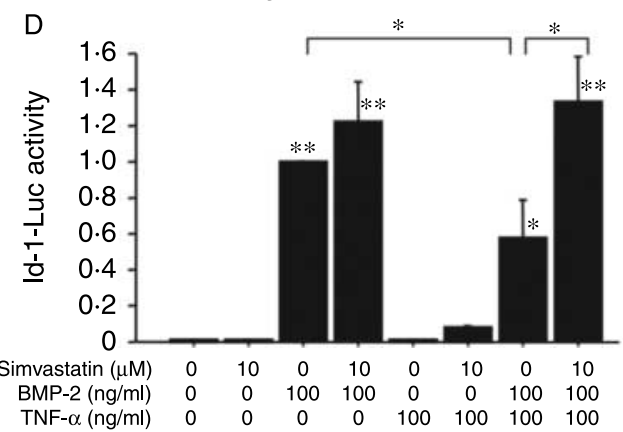

Figure 5 Effects of simvastatin and TNF- $\alpha$ on BMP-induced Smad signaling in C2C12 cells. (A and B) After preculture, cells were incubated with simvastatin $(10 \mu \mathrm{M})$ in combination with BMP-2 $(100 \mathrm{ng} / \mathrm{ml})$ and TNF- $\alpha(100 \mathrm{ng} / \mathrm{ml})$. After adding BMP-2 for $1-4 \mathrm{~h}$, cells were lysed and subjected to SDS-PAGE/immunoblot (IB) analysis using antibodies that detect phosphorylated Smad1,5,8 molecules (pSmad1,5,8) and actin. The results shown are representative of those obtained from three independent experiments. $(C)$ The relative integrated density of each protein band (B; the data of 3- and 4-h culture conditions) was digitized by NIH image J 1.34s. Results are shown as mean \pm S.E.M. of data from at least three separate experiments, each performed with triplicate samples. (D) Cells $\left(1 \times 10^{5}\right.$ viable cells) were transiently transfected with Id-1-Luc reporter plasmid (500 ng) and pCMV- $\beta$-gal. The cells were pretreated with simvastatin $(10 \mu \mathrm{M})$ in combination with BMP-2 $(100 \mathrm{ng} / \mathrm{ml})$ for $24 \mathrm{~h}$ and then incubated with TNF- $\alpha(100 \mathrm{ng} / \mathrm{ml})$. After $24-\mathrm{h}$ culture, the cells were washed with PBS, lysed and the luciferase and $\beta$-galactosidase ( $\beta$-gal) activities were measured by luminometer. The data were expressed as the ratio of luciferase to $\beta$-gal activity. Results are shown as mean \pm S.E.M. of data from at least three separate experiments, each performed with triplicate samples. ${ }^{*} P<0.05$ and ${ }^{* *} P<0 \cdot 01$ versus control groups or between the indicated groups.

markers including Runx2 and ALP activity stimulated by BMP-2 in which simvastatin impaired the TNF- $\alpha$ effects on BMP-2-induced osteogenetic process (Fig. 11).

Mundy et al. first reported that statins were potent stimulators of bone formation in vitro (Mundy et al. 1999). In that study, over 30000 compounds were screened for their ability to stimulate BMP-2 promoter in an immortalized murine osteoblast cell line. The rationale for the approach was that osteoblast differentiation is enhanced by BMPs, whereas other bone growth factors, such as TGFs and fibroblast growth factors (FGFs), stimulate osteoblast proliferation but inhibit osteoblast differentiation. In this regard, Sugiyama et al. (2000) also reported that simvastatin, but not pravastatin, induces BMP-2 expression in human osteosarcoma cells. In these experiments, the addition of mevalonate, the downstream metabolite of HMG-CoA reductase, inhibited the statin-mediated activation of BMP-2. Maeda et al. (2001) showed stimulatory effects of simvastatin on osteoblastic differentiation in transformed osteoblastic cells and rat bone marrow cells. It also was reported that statins sequentially induce the expression of stage-dependent markers for osteoblasts, leading to enhancement of osteoblast differentiation (Maeda et al. 2004). Thus, there has been accumulating evidence indicating that statins potentially elicit anabolic effects on the osteoblastic differentiation at various stages.

Regarding the functional interaction of statins and cellular BMP system, Hu et al. (2006) showed that simvastatin enhances BMP type-II receptor (BMPRII) gene expression in pulmonary artery smooth muscle cells and lung microvascular endothelial cells. Fluvastatin is reported to induce Id-1 expression in human dermal microvascular endothelial cells (Pammer et al. 2004). These data provided a convergence of BMP and statin signaling in induction of endothelial Id- 1 and implied that these pathways are functionally linked. In the present study, cDNA array analysis of BMP/TGF- $\beta$ signaling molecules demonstrated enhanced expression of Smad1,2,3 in C2C12 cells treated with simvastatin. Thus, it is likely that the increased Smad expression by simvastatin may be involved in augmenting BMP-induced Smad1,5,8 activation during the process of osteoblast differentiation. 
A

A
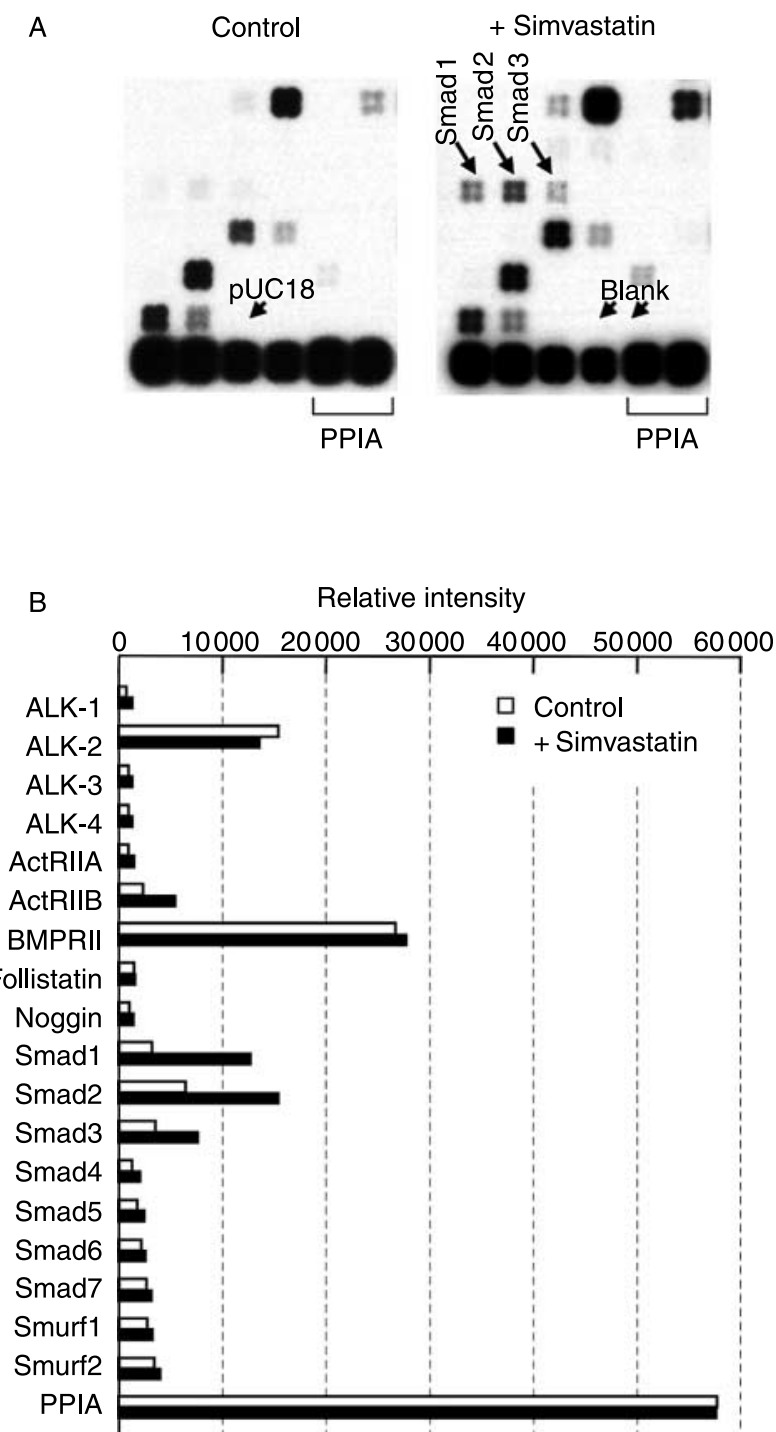

Figure 6 Simvastatin effects on the expression pattern of BMP system molecules in $\mathrm{C} 2 \mathrm{C} 12$ cells. (A) Total cellular RNAs were extracted from $\mathrm{C} 2 \mathrm{C} 12$ cells treated with TNF- $\alpha(10 \mathrm{ng} / \mathrm{ml})$ alone (control group) or simvastatin $(10 \mu \mathrm{M})$ in the presence of TNF- $\alpha$ $(10 \mathrm{ng} / \mathrm{ml})$ for $24 \mathrm{~h}$ (+simvastatin group). Total cellular RNAs $(2 \cdot 0 \mu \mathrm{g})$ were used as templates to generate biotin-16-dUTPlabeled cDNA probes for GEArray ${ }^{\circledR}$ membranes (SuperArray Bioscience Corp.) that include human TGF- $\beta$ and BMP signaling molecules. The cDNA probes were denatured and hybridized with the cDNA array membranes and then the membranes were washed and exposed to X-ray films using chemiluminescent substrate. (B) The spots on the X-ray films were scanned, digitized, and the signal intensities of the spots on the membranes obtained from two separate experiments were analyzed using the GEArray analyzer program (SuperArray Bioscience Corp.) after subtraction of the background levels of pUC18 DNA. Glyceraldehyde-3-phosphate dehydrogenase (GAPDH) and cyclophilin A (PPIA) are used as a positive control to compare the membranes.

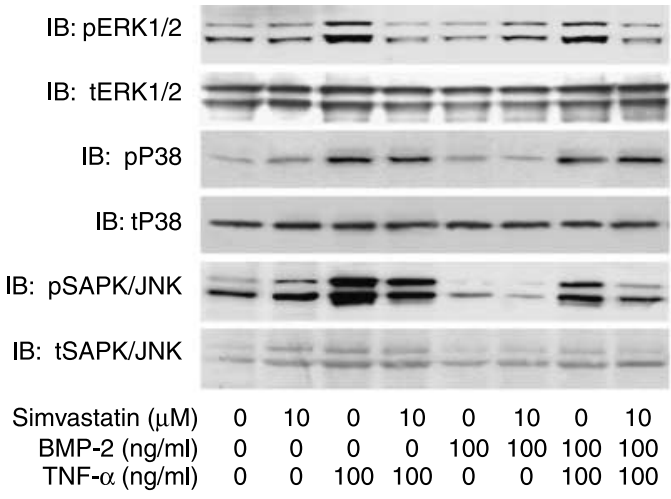

B

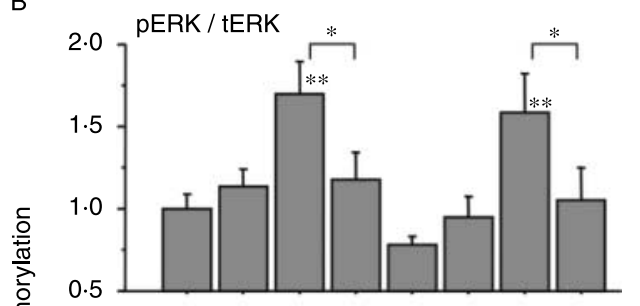

$3.0 \mathrm{pP} 38 / \mathrm{tP} 38$

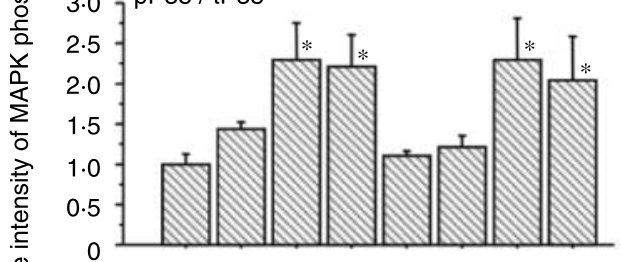

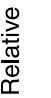

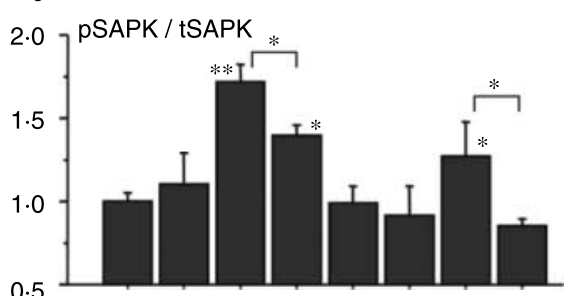

$\begin{array}{rcccccccc}\text { Simvastatin }(\mu \mathrm{M}) & 0 & 10 & 0 & 10 & 0 & 10 & 0 & 10 \\ \text { BMP-2 }(\mathrm{ng} / \mathrm{ml}) & 0 & 0 & 0 & 0 & 100 & 100 & 100 & 100 \\ \text { TNF- } \alpha(\mathrm{ng} / \mathrm{ml}) & 0 & 0 & 100 & 100 & 0 & 0 & 100 & 100\end{array}$

Figure 7 Effects of simvastatin and BMP-2 on TNF- $\alpha$-induced MAPK phosphorylation in $\mathrm{C} 2 \mathrm{C} 12$ cells. (A) After preculture, cells were incubated with simvastatin $(10 \mu \mathrm{M})$ in combination with BMP-2 $(100 \mathrm{ng} / \mathrm{ml})$ and TNF- $\alpha(100 \mathrm{ng} / \mathrm{ml})$. After adding TNF- $\alpha$ for $60 \mathrm{~min}$, cells were lysed and subjected to SDS-PAGE/immunoblot (IB) analysis using anti-phospho-ERK1/2 (pERK1/2), anti-total-ERK1/2 (tERK1/2), anti-phospho-P38 (pP38), anti-total-P38 (tP38), antiphospho-SAPK/JNK (pSAPK/JNK), and anti-total-SAPK/JNK (tSAPK/JNK) antibodies that detect phosphorylated MAPK signaling. The results shown are representative of those obtained from three independent experiments. (B) The relative integrated density of each protein band was digitized by NIH image J 1.34s. Results are shown as mean \pm s.E.M. of data from at least three separate experiments, each performed with triplicate samples. ${ }^{*} P<0.05$ and ${ }^{* *} P<0.01$ versus control or between the indicated groups. 
A IB: pan-Ras

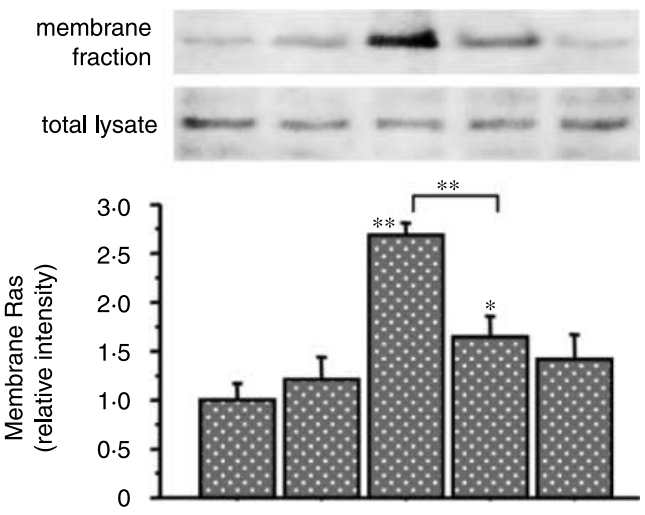

$\begin{array}{rccccc}\text { Simvastatin }(\mu \mathrm{M}) & 0 & 10 & 0 & 10 & 0 \\ \text { TNF- } \alpha(\mathrm{ng} / \mathrm{ml}) & 0 & 0 & 100 & 100 & 0 \\ \text { BMP-2 }(\mathrm{ng} / \mathrm{ml}) & 0 & 0 & 0 & 0 & 100\end{array}$

B IB: RhoA
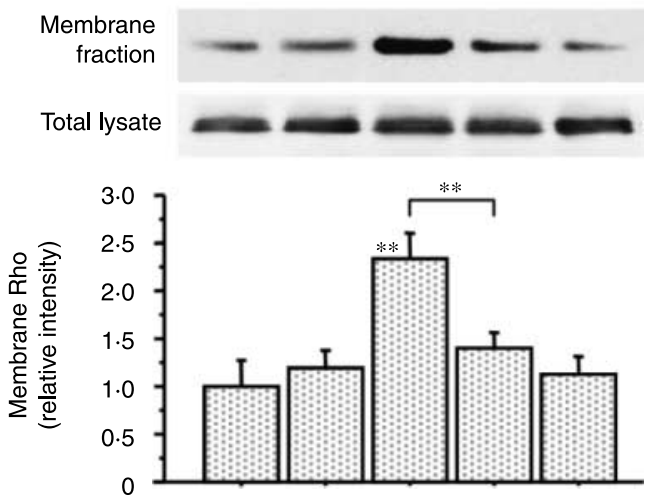

$\begin{array}{rccccc}\text { Simvastatin }(\mu \mathrm{M}) & 0 & 10 & 0 & 10 & 0 \\ \text { TNF- } \alpha(\mathrm{ng} / \mathrm{ml}) & 0 & 0 & 100 & 100 & 0 \\ \text { BMP-2 }(\mathrm{ng} / \mathrm{ml}) & 0 & 0 & 0 & 0 & 100\end{array}$

Figure 8 Simvastatin effects on TNF- $\alpha$-induced Ras/Rho membrane localization in $\mathrm{C} 2 \mathrm{C} 12$ cells. The cells were incubated with TNF- $\alpha$ $(100 \mathrm{ng} / \mathrm{ml})$ or BMP-2 $(100 \mathrm{ng} / \mathrm{ml})$ in combination with simvastatin $(10 \mu \mathrm{M})$. After adding TNF- $\alpha$ for $60 \mathrm{~min}$, total cellular protein and the membrane fractions were extracted and then subjected to SDSPAGE/immunoblot (IB) analysis using (A) anti-pan-Ras and (B) antiRhoA antibodies. The results shown are representative of those obtained from three independent experiments. The relative integrated density of each protein band was digitized by NIH image J 1.34s. Results are shown as mean \pm s.E.M. of data from at least three separate experiments, each performed with triplicate samples. ${ }^{*} P<0.05$ and ${ }^{* *} P<0.01$ versus control or between the indicated groups.

TNF- $\alpha$ is a pleiotropic cytokine produced by activated macrophages, which signals through two distinct surface receptors, TNFR1 and TNFR2 (Baud \& Karin 2001, Chen \& Goeddel 2002). TNF- $\alpha$ has been recognized as a potent stimulator of bone resorption (Mundy 1993) via TNFR1
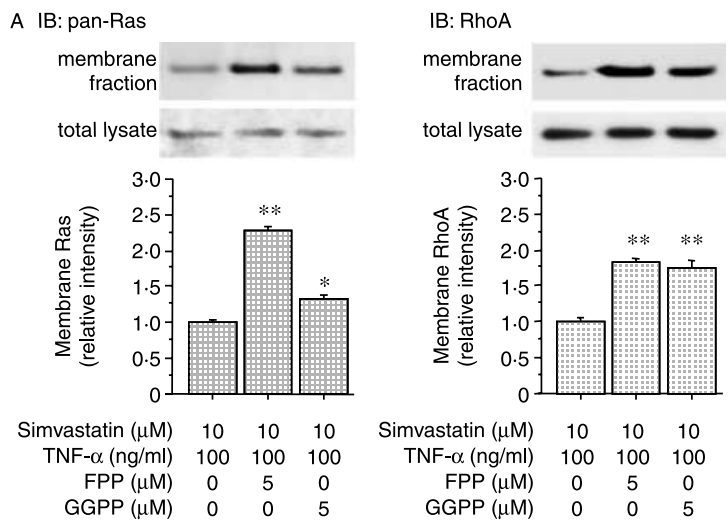

B
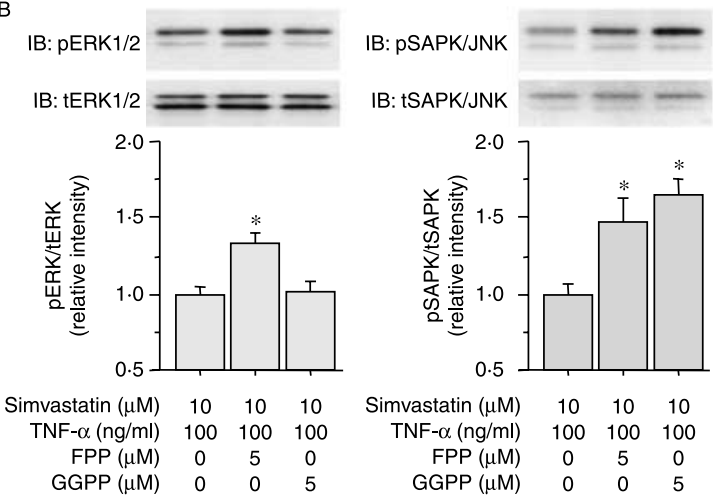

C
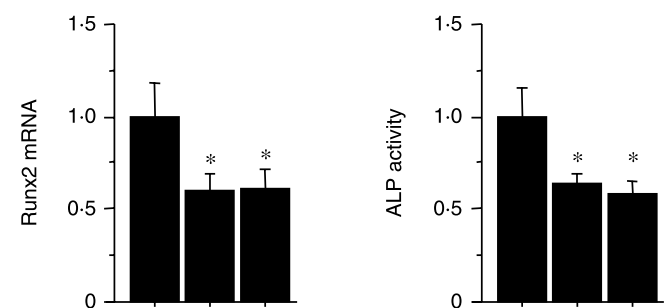

Simvastatin $(\mu \mathrm{M}) \quad 10 \quad 10 \quad 10$ BMP-2 (ng/ml) $100 \quad 100 \quad 100$ TNF- $\alpha(\mathrm{ng} / \mathrm{ml}) \quad 10 \quad 10 \quad 10$ $\begin{array}{rlll}\text { FPP }(\mu M) & 0 & 5 & 0 \\ \text { GGPP }(\mu M) & 0 & 0 & 5\end{array}$

Simvastatin $(\mu \mathrm{M}) \quad 10 \quad 10 \quad 10$ BMP-2 (ng/ml) $100 \quad 100 \quad 100$ TNF- $\alpha(n g / m l) \quad 10 \quad 10 \quad 10$ $\begin{array}{rlll}\operatorname{FPP}(\mu \mathrm{M}) & 0 & 5 & 0\end{array}$

Figure 9 Effects of farnesyl pyrophosphate (FPP) and geranylgeranyl pyrophosphate (GGPP) on simvastatin actions in $\mathrm{C} 2 \mathrm{C} 12$ cells. (A and B) Cells were incubated with TNF- $\alpha(100 \mathrm{ng} / \mathrm{ml})$ in combination with simvastatin $(10 \mu \mathrm{M})$ and either FPP $(5 \mu \mathrm{M})$ or GGPP $(5 \mu \mathrm{M})$. After adding TNF- $\alpha$ for $60 \mathrm{~min}$, protein fractions were subjected to SDS-PAGE/immunoblot (IB) analysis for detection of (A) Ras and RhoA (see Fig. 8 legend) and (B) ERK1/2 and SAPK/JNK phosphorylation (see Fig. 7 legend). The results shown are representative of those obtained from three independent experiments. The relative integrated density of each protein band was digitized by NIH image J 1.34s. (C) Cells were pretreated with simvastatin $(10 \mu \mathrm{M})$, BMP-2 $(100 \mathrm{ng} / \mathrm{ml})$ and either FPP $(5 \mu \mathrm{M})$ or GGPP $(5 \mu \mathrm{M})$ for $24 \mathrm{~h}$. After treatment with TNF- $\alpha(10 \mathrm{ng} / \mathrm{ml})$, cells were subjected to Runx2 mRNA analysis and ALP assay (see Figs 3 and 4 legends). Results are shown as mean \pm s.E.M. of data from at least three separate experiments, each performed with triplicate samples. ${ }^{*} P<0.05$ and ${ }^{* *} P<0 \cdot 01$ versus control groups. 

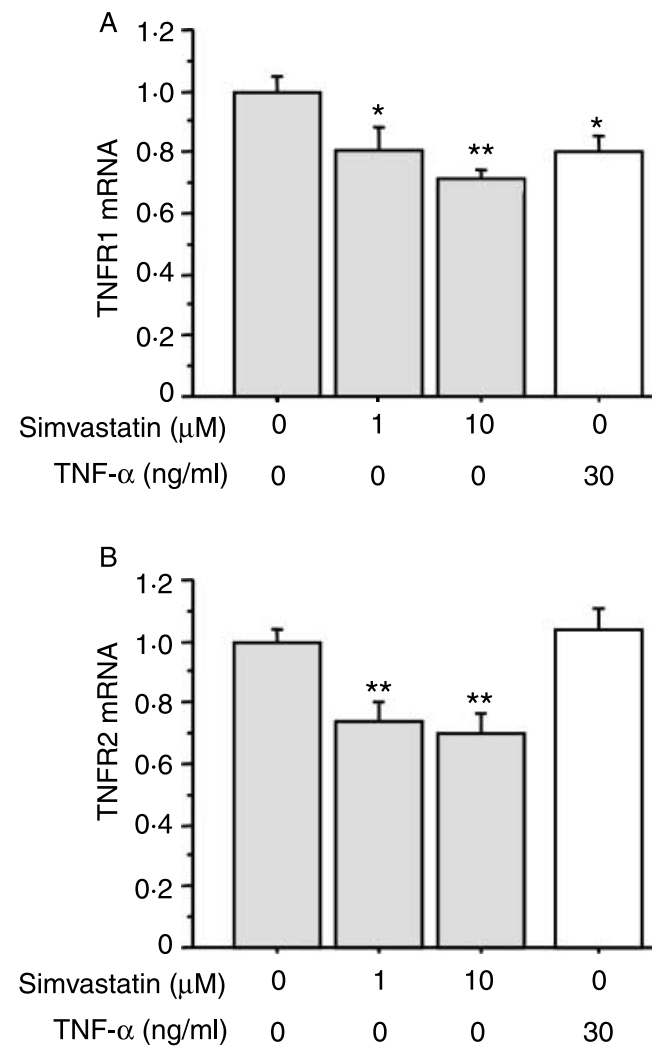

Figure 10 Effects of simvastatin on TNF receptor expression by C2C12 cells. After preculture, the cells were treated with simvastatin $(1$ and $10 \mu \mathrm{M})$ and TNF- $\alpha(30 \mathrm{ng} / \mathrm{ml})$ for $24 \mathrm{~h}$. Total cellular RNA was extracted and subjected to RT reaction. For the quantification of TNF type-1 (A): TNFR1, type-2 receptors (B): TNFR2, and RPL19 mRNA levels, qPCR analysis was performed. The expression levels of target genes were standardized by RPL19 level in each sample. Results are shown as mean \pm s.E.M. of data from at least three separate experiments, each performed with triplicate samples. ${ }^{*} P<0.05$ and ${ }^{* *} P<0.01$ versus control groups.

signaling. The cytoplasmic tail of TNFR1 contains a death domain (DD), which is essential for induction of apoptosis; however, this motif is missing in TNFR2 and the function of this receptor is poorly understood (MacEwan 2002). In this study, simvastatin reduced the expression of both TNFR1 and TNFR 2 in C2C12 cells (Fig. 11). The expression of TNFR1 and TNFR 2 in monocytes has been shown to be modulated by various cytokines including TNF- $\alpha$, interleukin-10, and macrophage-colony stimulating factor (Takasugi et al. 2006). With regard to the effects of TNF- $\alpha$ on osteoblast differentiation, Chen and colleagues suggested a new linkage between BMP and TNF system, showing that BMP-2 and BMP-4 inhibited TNF- $\alpha$-mediated apoptosis in a NF- $\kappa$ Bindependent manner by inhibition of caspase- 8 activation in C2C12 cells (Chen et al. 2001). This finding suggests that BMPs not only stimulate osteoblast differentiation but also promote cell survival during osteogenetic process.
There has been recent evidence indicating that the effects of TNF- $\alpha$ are primarily associated with activation of MAPK signaling, which subsequently increases the activation of stress-related proteins such as NF- $\mathrm{BB}$ and suppressor of cytokine signaling (SOCS; Wajant et al. 2003). Frost et al. (2003a) reported that TNF- $\alpha$ stimulated the phosphorylation of SAPK/JNK pathway in C2C12 cells and that the specific inhibition of SAPK/JNK activation, but not other MAPK pathways, prevented TNF- $\alpha$-induced drop of IGF-I expression. They also showed that SAPK/JNK inhibition blocked TNF-induced IL-6 synthesis in C2C12 cells, suggesting the significance of SAPK/JNK pathway for modulating inflammatory responses in $\mathrm{C} 2 \mathrm{C} 12$ cells (Frost et al. 2003b). In this regard, we recently showed that TNF- $\alpha$ effects on inhibition of osteogenic process are mediated, at least in part, by the activation of SAPK/JNK pathway and the suppression of an inhibitory Smad6 expression in C2C12 cells (Mukai et al. 2007). In the present study, we report that simvastatin potently suppresses TNF- $\alpha$-induced phosphorylation of ERK1/2 and SAPK/JNK but not P38 pathways. Thus, simvastatin supports BMP-induced osteoblast differentiation through antagonizing TNF- $\alpha$-to-MAPK pathway as well as augmenting BMP-Smad signaling (Fig. 11).

Inhibition of simvastatin in TNF- $\alpha$-induced ERK1/2 and SAPK/JNK phosphorylation is likely due to the suppression of small molecular weight G-proteins Ras/Rho in the process of osteoblast differentiation. In our study, TNF- $\alpha$ increased the levels of membrane-bound Ras and RhoA, and simvastatin prevented TNF- $\alpha$-induced membrane localization of Ras/Rho without affecting the total amount of these proteins in $\mathrm{C} 2 \mathrm{C} 12$ cells (Fig. 11). Activation of the mevalonate pathway leads to the production of intermediates, such as FPP and GGPP, which activate Ras and Rho by posttranslational modification (Liao \& Laufs 2005). Ras/Rho proteins are involved in many of cellular functions such as cell proliferation, differentiation, apoptosis, migration, contraction, and regulation of gene transcription (Liao \& Laufs 2005). Activated Ras/Rho proteins are key components in signal-transducing kinase cascades including MAPKs (Shirai et al. 2007). The anchoring of these small G-proteins to cell membranes requires prenylation. Ras proteins are farnesylated and Rho proteins are geranylgeranylated (Liao \& Laufs 2005). Small G-proteins exist in an inactive GDP-bound cytosolic form and upon cellular activation they exchange GTP and translocate to the active membrane form (Auer et al. 2002). By inhibiting this isoprenylation, statins lower membrane levels and activity of Ras/Rho proteins (Auer et al. 2002). Based on our results, this process presumably accounts for the present simvastatin effects on antagonizing TNF- $\boldsymbol{\alpha}$-to-MAPK cascade in $\mathrm{C} 2 \mathrm{C} 12$ cells (Fig. 11). In this regard, Fromigué et al. (2006) reported that lipophilic statins facilitate membrane RhoA relocalization to the cytosol and decrease phosphorylation of ERK1/2 by human osteosarcoma cells. It is further shown that statins induce caspase-dependent apoptosis of osteosarcoma cells through RhoA-MAPK-Bcl-2 pathway independently of BMP-2 signaling (Fromigue et al. 


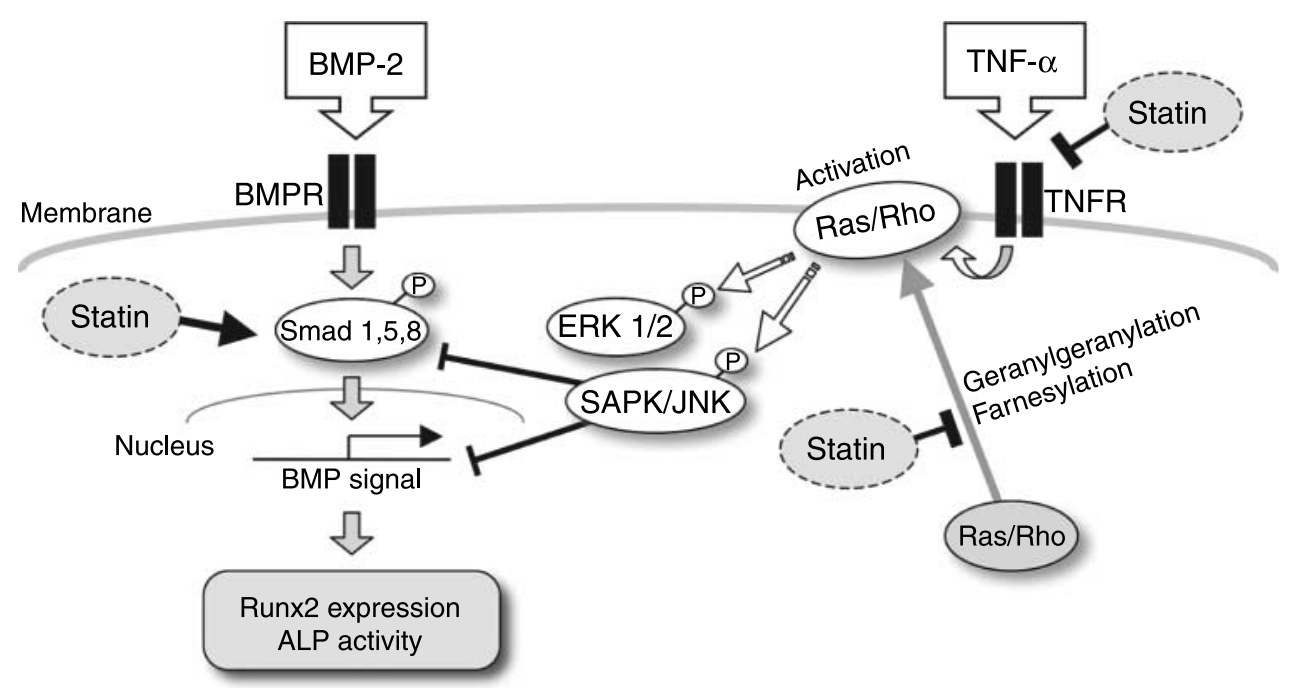

Figure 11 A mechanism by which simvastatin antagonizes TNF- $\alpha$ inhibition on BMP-2-induced osteoblastic differentiation. Simvastatin supports BMP-2-induced osteoblast differentiation shown as Runx2 expression and ALP activation through antagonizing TNF- $\alpha$-to-MAPK pathway and augmenting Smad1,5,8 signaling. SAPK/JNK pathway which is induced by TNF- $\alpha$ is a major regulator for suppressing BMP signaling (Mukai et al. 2007). Activation of mevalonate pathway leads to post-translational modification of Ras and Rho such as farnesylation and geranylgeranylation. Activated Ras/Rho proteins are key components for signaltransducing kinase cascades including ERK1/2 and SAPK/JNK. Simvastatin prevents TNF- $\alpha$-induced membrane localization of Ras/Rho and also reduces the expression of TNFR in C2C12 cells.

2006). Ohnaka et al. (2001) have demonstrated stimulatory effects of pitavastatin on the expression of BMP-2 and osteocalcin mRNA in primary cultured human osteoblasts, in which Rho-kinase inhibition was shown as the major mechanism of statin-induced osteoblastic differentiation. Ghosh-Choudhury et al. (2007) showed possible signaling crosstalk for the statin-induced osteoblast differentiation. In their study, a lipophilic lovastatin-stimulated Ras activation in osteoblast precursor 2T3 cells, leading to phosphatidylinositol-3-kinase (PI3K) activation, which in turn regulates Akt and ERK phosphorylation to induce BMP-2 expression for osteoblast differentiation (Ghosh-Choudhury et al. 2007). Future investigation is necessary to elucidate the underlying mechanism by which statins elicit differential effects on MAPK pathways through $\mathrm{Rho/R}$ as inactivation in the process of osteoblast differentiation.

Taken together with our present data, statins stimulate osteoblast differentiation and matrix mineralization in vitro, which implicates clinical applicability of statins for treating osteoporosis. In addition to the effects of statins on endogenous cholesterol levels by inhibiting HMG-CoA reductase, statins also have pleiotropic effects such as antiinflammatory, anti-proliferative, and anti-thrombotic effects (Rosenson et al. 1999, Bellosta et al. 2000). Although effects of statins on bone mass and bone turnover remain controversial, increased bone mass, and reduced bone turnover have been observed in patients treated with statins (Garrett \& Mundy 2002). The Mundy et al. (1999) initial rodent experiments were remarkable for not only the statin's effects on bone formation but also the anti-resorptive effects since animals given oral simvastatin had a significant reduction in osteoclast number. Additional evidence that statins may have an antiresorptive effect has been shown by Woo et al. (2000) using an in vitro assay for osteoclast formation (Takahashi et al. 1988), suggesting that statins also exert inhibitory effects on the differentiation of osteoclasts by interfering with the fusion process by which osteoclast precursors develop into multinucleated osteoclast-like cells. Many clinical studies have suggested that statin use is associated with a reduced risk of bone fractures; however, only a modest increase in bone mass and inconsistent effects on bone turnover have been reported to date (Bauer 2003, Jadhav \& Jain 2006). Given that $<5 \%$ of an oral dose statin reaches the systemic circulation (Bellosta et al. 2000), osteoblasts and osteoclasts are exposed to very low concentrations of statin with usual oral regimens. Specific statins with high affinity to bone tissues would be useful for prevention or treatment of osteoporosis due to inflammatory cytokines associated with rheumatoid arthritis.

\section{Acknowledgements}

We thank Dr R Kelly Moore for helpful discussion and critical reading of the manuscript. We also thank Drs Tetsuro Watabe and Kohei Miyazono for providing Id-1-Luc plasmid. This work was supported in part by Grants-in-Aid for 
Scientific Research, Life Science Foundation of Japan, Takeda Science Foundation, Sakakibara Memorial Research Grant, The Kawasaki Foundation for Medical Science and Medical Welfare, The Ichiro Kanahara Foundation, Kato Memorial Bioscience Foundation, Terumo Lifescience Foundation, and Japan Rheumatism Foundation. The authors declare that there is no conflict of interest that would prejudice the impartiality of this scientific work.

\section{References}

Auer J, Berent R, Weber T \& Eber B 2002 Clinical significance of pleiotropic effects of statins: lipid reduction and beyond. Current Medicinal Chemistry 9 $1831-1850$

Baud V \& Karin M 2001 Signal transduction by tumor necrosis factor and its relatives. Trends in Cell Biology 11 372-377.

Bauer DC 2003 HMG CoA reductase inhibitors and the skeleton: a comprehensive review. Osteoporosis International 14 273-282.

Bellosta S, Ferri N, Bernini F, Paoletti R \& Corsini A 2000 Non-lipid-related effects of statins. Annals of Medicine 32 164-176.

Casey PJ \& Seabra MC 1996 Protein prenyltransferases. Journal of Biological Chemistry 271 5289-5292.

Celeste AJ, Iannazzi JA, Taylor RC, Hewick RM, Rosen V, Wang EA \& Wozney JM 1990 Identification of transforming growth factor beta family members present in bone-inductive protein purified from bovine bone. PNAS 87 9843-9847.

Chen G \& Goeddel DV 2002 TNF-R1 signaling: a beautiful pathway. Science 296 1634-1635.

Chen S, Guttridge DC, Tang E, Shi S, Guan K \& Wang CY 2001 Suppression of tumor necrosis factor-mediated apoptosis by nuclear factor $\mathrm{\kappa B}$-independent bone morphogenetic protein/Smad signaling. Journal of Biological Chemistry 276 39259-39263.

Ducy P, Zhang R, Geoffroy V, Ridall AL \& Karsenty G 1997 Osf2/Cbfa1: a transcriptional activator of osteoblast differentiation. Cell 89 747-754.

Ebisawa T, Tada K, Kitajima I, Tojo K, Sampath TK, Kawabata M, Miyazono K \& Imamura T 1999 Characterization of bone morphogenetic protein-6 signaling pathways in osteoblast differentiation. Journal of Cell Science $\mathbf{1 1 2}$ 3519-3527.

Feldmann M \& Maini RN 2001 Anti-TNF alpha therapy of rheumatoid arthritis: what have we learned? Annual Review of Immunology 19 163-196.

Feldmann M, Brennan FM \& Maini RN 1996 Role of cytokines in rheumatoid arthritis. Annual Review of Immunology 14 397-440.

Fromigue O, Hay E, Modrowski D, Bouvet S, Jacquel A, Auberger P \& Marie PJ 2006 RhoA GTPase inactivation by statins induces osteosarcoma cell apoptosis by inhibiting $\mathrm{p} 42 / \mathrm{p} 44-\mathrm{MAPKs}-\mathrm{Bcl}-2$ signaling independently of BMP-2 and cell differentiation. Cell Death and Differentiation 13 1845-1856.

Frost RA, Nystrom GJ \& Lang CH 2003a Tumor necrosis factor-alpha decreases insulin-like growth factor-I messenger ribonucleic acid expression in $\mathrm{C} 2 \mathrm{C} 12$ myoblasts via a Jun N-terminal kinase pathway. Endocrinology 144 1770-1779.

Frost RA, Nystrom GJ \& Lang CH $2003 b$ Lipopolysaccharide and proinflammatory cytokines stimulate interleukin-6 expression in $\mathrm{C} 2 \mathrm{C} 12$ myoblasts: role of the Jun NH2-terminal kinase. American Journal of Physiology, Regulatory, Integrative and Comparative Physiology 285 R1153-R1164.

Garrett IR \& Mundy GR 2002 The role of statins as potential targets for bone formation. Arthritis Research 4 237-240.

Gerber HP, Vu TH, Ryan AM, Kowalski J, Werb Z \& Ferrara N 1999 VEGF couples hypertrophic cartilage remodeling, ossification and angiogenesis during endochondral bone formation. Nature Medicine 5 623-628.

Ghosh-Choudhury N, Mandal CC \& Choudhury GG 2007 Statin-induced Ras activation integrates the phosphatidylinositol 3-kinase signal to Akt and MAPK for bone morphogenetic protein-2 expression in osteoblast differentiation. Journal of Biological Chemistry 282 4983-4993.
Goad DL, Rubin J, Wang H, Tashjian AH Jr \& Patterson C 1996 Enhanced expression of vascular endothelial growth factor in human $\mathrm{SaOS}-2$ osteoblast-like cells and murine osteoblasts induced by insulin-like growth factor I. Endocrinology 137 2262-2268.

Goldstein JL \& Brown MS 1990 Regulation of the mevalonate pathway. Nature 343 425-430.

Hamelin BA \& Turgeon J 1998 Hydrophilicity/lipophilicity: relevance for the pharmacology and clinical effects of HMG-CoA reductase inhibitors. Trends in Pharmacological Sciences 19 26-37.

Hu H, Sung A, Zhao G, Shi L, Qiu D, Nishimura T \& Kao PN 2006 Simvastatin enhances bone morphogenetic protein receptor type II expression. Biochemical and Biophysical Research Communications 339 59-64.

Hughes FJ, Collyer J, Stanfield M \& Goodman SA 1995 The effects of bone morphogenetic protein $-2,-4$, and -6 on differentiation of rat osteoblast cells in vitro. Endocrinology 136 2671-2677.

Inagaki K, Otsuka F, Suzuki J, Kano Y, Takeda M, Miyoshi T, Otani H, Mimura Y, Ogura T \& Makino H 2006 Involvement of bone morphogenetic protein- 6 in differential regulation of aldosterone production by angiotensin II and potassium in human adrenocortical cells. Endocrinology 147 2681-2689.

Jadhav SB \& Jain GK 2006 Statins and osteoporosis: new role for old drugs. Journal of Pharmacy and Pharmacology 58 3-18.

Kano Y, Otsuka F, Takeda M, Suzuki J, Inagaki K, Miyoshi T, Miyamoto M, Otani H, Ogura T \& Makino H 2005 Regulatory roles of bone morphogenetic proteins and glucocorticoids in catecholamine production by rat pheochromocytoma cells. Endocrinology 146 5332-5340.

Katagiri T, Yamaguchi A, Komaki M, Abe E, Takahashi N, Ikeda T, Rosen V, Wozney JM, Fujisawa-Sehara A \& Suda T 1994 Bone morphogenetic protein-2 converts the differentiation pathway of $\mathrm{C} 2 \mathrm{C} 12$ myoblasts into the osteoblast lineage. Journal of Cell Biology 127 1755-1766.

Komori T, Yagi H, Nomura S, Yamaguchi A, Sasaki K, Deguchi K, Shimizu Y, Bronson RT, Gao YH, Inada M et al. 1997 Targeted disruption of Cbfa1 results in a complete lack of bone formation owing to maturational arrest of osteoblasts. Cell 89 755-764.

Kudo O, Fujikawa Y, Itonaga I, Sabokbar A, Torisu T \& Athanasou NA 2002 Proinflammatory cytokine (TNFalpha/IL-1alpha) induction of human osteoclast formation. Journal of Pathology 198 220-227.

Liao JK \& Laufs U 2005 Pleiotropic effects of statins. Annual Review of Pharmacology and Toxicology 45 89-118.

Lieberman JR, Daluiski A \& Einhorn TA 2002 The role of growth factors in the repair of bone. Biology and clinical applications. Journal of Bone and Joint Surgery, American Volume 84-A 1032-1044.

MacEwan DJ 2002 TNF receptor subtype signalling: differences and cellular consequences. Cellular Signalling 14 477-492.

Maeda T, Matsunuma A, Kawane T \& Horiuchi N 2001 Simvastatin promotes osteoblast differentiation and mineralization in MC3T3-E1 cells. Biochemical and Biophysical Research Communications 280 874-877.

Maeda T, Kawane T \& Horiuchi N 2003 Statins augment vascular endothelial growth factor expression in osteoblastic cells via inhibition of protein prenylation. Endocrinology 144 681-692.

Maeda T, Matsunuma A, Kurahashi I, Yanagawa T, Yoshida H \& Horiuchi N 2004 Induction of osteoblast differentiation indices by statins in MC3T3-E1 cells. Journal of Cellular Biochemistry 92 458-471.

Maron DJ, Fazio S \& Linton MF 2000 Current perspectives on statins. Circulation 101 207-213.

McCarthy TL, Centrella M \& Canalis E 1989 Regulatory effects of insulinlike growth factors I and II on bone collagen synthesis in rat calvarial cultures. Endocrinology 124 301-309.

Midy V \& Plouet J 1994 Vasculotropin/vascular endothelial growth factor induces differentiation in cultured osteoblasts. Biochemical and Biophysical Research Communications 199 380-386.

Miyoshi T, Otsuka F, Suzuki J, Takeda M, Inagaki K, Kano Y, Otani H, Mimura Y, Ogura T \& Makino H 2006 Mutual regulation of folliclestimulating hormone signaling and bone morphogenetic protein system in human granulosa cells. Biology of Reproduction 74 1073-1082. 
Mukai T, Otsuka F, Otani H, Yamashita M, Takasugi K, Inagaki K, Yamamura M \& Makino H 2007 TNF-alpha inhibits BMP-induced osteoblast differentiation through activating SAPK/JNK signaling. Biochemical and Biophysical Research Communications 356 1004-1010.

Mundy GR 1993 Cytokines and growth factors in the regulation of bone remodeling. Journal of Bone and Mineral Research 8 (Suppl 2) S505-S510.

Mundy G, Garrett R, Harris S, Chan J, Chen D, Rossini G, Boyce B, Zhao M \& Gutierrez G 1999 Stimulation of bone formation in vitro and in rodents by statins. Science 286 1946-1949.

Noda M \& Camilliere JJ 1989 In vivo stimulation of bone formation by transforming growth factor-beta. Endocrinology 124 2991-2994.

Ohnaka K, Shimoda S, Nawata H, Shimokawa H, Kaibuchi K, Iwamoto Y \& Takayanagi R 2001 Pitavastatin enhanced BMP-2 and osteocalcin expression by inhibition of Rho-associated kinase in human osteoblasts. Biochemical and Biophysical Research Communications 287 337-342.

Otani H, Otsuka F, Inagaki K, Takeda M, Miyoshi T, Suzuki J, Mukai T, Ogura T \& Makino H 2007 Antagonistic effects of bone morphogenetic protein- 4 and -7 on renal mesangial cell proliferation induced by aldosterone through MAPK activation. American Journal of Physiology, Renal Physiology 292 F1513-F1525.

Otsuka F \& Shimasaki S 2002 A novel function of bone morphogenetic protein-15 in the pituitary: selective synthesis and secretion of FSH by gonadotropes. Endocrinology 143 4938-4941.

Otsuka F, Yao Z, Lee TH, Yamamoto S, Erickson GF \& Shimasaki S 2000 Bone morphogenetic protein-15: identification of target cells and biological functions. Journal of Biological Chemistry 275 39523-39528.

Otto F, Thornell AP, Crompton T, Denzel A, Gilmour KC, Rosewell IR, Stamp GW, Beddington RS, Mundlos S, Olsen BR et al. 1997 Cbfa1, a candidate gene for cleidocranial dysplasia syndrome, is essential for osteoblast differentiation and bone development. Cell 89 765-771.

Pammer J, Reinisch C, Kaun C, Tschachler E \& Wojta J 2004 Inhibitors of differentiation/DNA binding proteins Id 1 and Id 3 are regulated by statins in endothelial cells. Endothelium 11 175-180.

Reddi AH 1997 Bone morphogenetic proteins: an unconventional approach to isolation of first mammalian morphogens. Cytokine and Growth Factor Reviews 8 11-20.

Rosenson RS, Tangney CC \& Casey LC 1999 Inhibition of proinflammatory cytokine production by pravastatin. Lancet 353 983-984.

Scott DL \& Kingsley GH 2006 Tumor necrosis factor inhibitors for rheumatoid arthritis. New England Journal of Medicine 355 704-712.

Shimasaki S, Moore RK, Otsuka F \& Erickson GF 2004 The bone morphogenetic protein system in mammalian reproduction. Endocrine Reviews 25 72-101.
Shirai H, Autieri M \& Eguchi S 2007 Small GTP-binding proteins and mitogenactivated protein kinases as promising therapeutic targets of vascular remodeling. Current Opinion in Nephrology and Hypertension 16 111-115.

Spelsberg TC, Subramaniam M, Riggs BL \& Khosla S 1999 The actions and interactions of sex steroids and growth factors/cytokines on the skeleton. Molecular Endocrinology 13 819-828.

Sugiyama M, Kodama T, Konishi K, Abe K, Asami S \& Oikawa S 2000 Compactin and simvastatin, but not pravastatin, induce bone morphogenetic protein-2 in human osteosarcoma cells. Biochemical and Biophysical Research Communications 271 688-692.

Suzuki J, Otsuka F, Inagaki K, Takeda M, Ogura T \& Makino H 2004 Novel action of activin and bone morphogenetic protein in regulating aldosterone production by human adrenocortical cells. Endocrinology 145 639-649.

Suzuki J, Otsuka F, Takeda M, Inagaki K, Miyoshi T, Mimura Y, Ogura T, Doihara H \& Makino H 2005 Functional roles of the bone morphogenetic protein system in thyrotropin signaling in porcine thyroid cells. Biochemical and Biophysical Research Communications 327 1124-1130.

Takahashi N, Yamana H, Yoshiki S, Roodman GD, Mundy GR, Jones SJ, Boyde A \& Suda T 1988 Osteoclast-like cell formation and its regulation by osteotropic hormones in mouse bone marrow cultures. Endocrinology 122 1373-1382.

Takasugi K, Yamamura M, Iwahashi M, Otsuka F, Yamana J, Sunahori K, Kawashima M, Yamada M \& Makino H 2006 Induction of tumour necrosis factor receptor-expressing macrophages by interleukin-10 and macrophage colony-stimulating factor in rheumatoid arthritis. Arthritis Research and Therapy 8 R 126.

Takeda M, Otsuka F, Nakamura K, Inagaki K, Suzuki J, Miura D, Fujio H, Matsubara H, Date H, Ohe T et al. 2004 Characterization of the bone morphogenetic protein (BMP) system in human pulmonary arterial smooth muscle cells isolated from a sporadic case of primary pulmonary hypertension: roles of BMP type IB receptor (activin receptor-like kinase-6) in the mitotic action. Endocrinology 145 4344-4354.

Wajant H, Pfizenmaier K \& Scheurich P 2003 Tumor necrosis factor signaling. Cell Death and Differentiation 10 45-65.

Woo JT, Kasai S, Stern PH \& Nagai K 2000 Compactin suppresses bone resorption by inhibiting the fusion of prefusion osteoclasts and disrupting the actin ring in osteoclasts. Journal of Bone and Mineral Research 15 650-662.

\section{Received in final form 15 December 2007}

Accepted 3 January 2008

Made available online as an Accepted Preprint 3 January 2008 